Lane, J. E. (1896). Brit. med. J. 2, 1702

Lane, J. R., and Gascoyen, G. G. (1867). " Record of Cases Treated in the Lock Hospital by Syphilization." Med.-chir. Trans., 50, 281.

Ricord, P. (1852). “Traité de la Maladie Vénérienne," a translation of John Hunter's "Treatise on Syphilis" with notes by Ricord. Paris. p. 43 .
Sazerac, R., and Levaditi, C. (1921). C. R. Soc. Biol., Paris, $85,30$.

Turner, Daniel (1733). “The Ancient Physician's Legacy Impartially. Surveyed," London. p. 144.

Wagner-Jauregg, J. (1918). "Malaria Impfungen bei Paralyse." Psych. neur. Wschr., 20, 132.

Wallace, William (1835-6). Lancet, $2,5$. (1836-7). Lancet, 2, 534, 615.

\title{
DISCUSSION ON THE HISTORY OF THE TREATMENT OF SYPHILIS
}

Col. HARRISON asked Mr. Abraham what he thought of the condition of that famous optimist, Dr. Pangloss, mentioned in Voltaire's Candide when Candide met him " all covered over with sores, his eyes half dead, the tip of his nose eaten off, his mouth turned to one side, his teeth black, speaking through his throat, tormented with a violent cough, with gums so rotten, that his teeth came near falling out every time he spit." It seemed to be a description of syphilis with mercurial poisoning.

He thought there might have been some reason for identifying gonorrhœa with syphilis because mercury did have an effect on gonorrhœa. He remembered that during the 1914-18 war an article appeared in a medical journal purporting to show that $100 \mathrm{mg}$. succinimide of mercury injected every other day for three or more doses cured gonorrhrea in about ten days. It did seem to have a rapid effect in reducing the discharge, so that large numbers of cases in his hospital seemed to be cured in less than a fortnight, and his medical officers became quite enthusiastic over it. The alleged cures did not stand a close examination, as a gleet persisted. Nevertheless the effect of the succinimide had been so striking that he had tried a number of mercurial compounds, but when 7,000 cases had been treated on these lines he had concluded that nothing had been gained. He judged that the great reduction of the discharge had been due to the mercury knocking out the reactive power of the tissues, and, in fact, these mercury-treated cases took longer to clear up than those treated on ordinary lines of the period. The action on the reactive power of the tissues might explain the effect of mercurial treatment on the Wassermann reaction in cases that seemed to be Wassermann-fast on arsenical and bismuth treatment.

He remembered before the 1914-18 war a man who had a very profitable pitch in Parliament Square, selling sarsaparilla drinks from a cart. When he was an assistant to the Professor of Medicine at Millbank he treated a patient who was going downhill with syphilis of a lung by giving him Zittmann's Decoction, and the effect was gratifying.

Under the late Col. Lambkin large numbers of patients had been treated with atoxyl at the Military Hospital, Rochester Row, without the slightest damage to their eyesight. Col. Lambkin was a great enthusiast for this form of treatment. He (Col. Harrison) strongly suspected that the damage to the eyes mentioned by $\mathrm{Mr}$. Abraham had been caused by boiling the atoxyl solution.

Dr. David Nabarro said he had recently read the Nonesuch edition of the works of John Wilmot, Earl of Rochester, who died, at the very early age of 33 of a disease which was thought to be syphilis. His mother wrote a-letter to her sister in which these words occurred : " He drinks asses' milk and it digests well with him." At the end of the book there was a note which said that venereal disorders were treated by administering the milk of an ass that had been subjected to inunctions of mercury. Could Mr. Johnston Abraham say when that method came into vogue? It gave the patient the advantage of mercurial inunction without the disadvantages.

He would also confirm Col. Harrison's remarks about atoxyl. He thought that it was used in quite a large number of cases of sleeping sickness, and ordinarily it did not produce symptoms of blindness.

DR. FESSLER pointed out that Mr. Johnston Abraham dealt with the treatment of syphilis by the medical profession. According to leaflets and newspaper advertisements, however, the treatment of venereal diseases by quacks seemed to have been rather widespread in this country during the eighteenth and nineteenth centuries. Of course one did not know what the different pills and medicines contained (? sarsaparilla). It was interesting to note that all the advertisements and leaflets stressed that the drugs were harmless because they did not contain mercury.

The speaker mentioned the treatment of syphilis with malaria. Wagner-Jauregg thought that malaria has a specific influence on syphilis. This idea led Kyrle at Finger's clinic in Vienna in the earlier twenties to carry out a large-scale experiment of treatment of primary and secondary syphilis with malaria. This treatment had soon to be abandoned; nevertheless this experiment had not been without value because it led to the treatment of gonorrhœa with malaria.

MAJOR SCOTT said that just before the war he visited Italy and went to Pompeii, and there he saw certain members which he was told were those of syphilitics, and he saw clavicles and tibiæ which were typical of those seen in congenital syphilis. It was well known that this disease was common in the Roman Army; in fact he thought Nero was supposed to have had it.

DR. RoberT LeES remarked that the modern history of venereal disease was as full of interest as the ancient. He had recently read Janos, a book by Dr. John Plesch in which the author gave interesting studies of Schaudinn, Hoffman, Wassermann, and Ehrlich. He had met some time ago a man who claimed that he was present when Ehrlich received the first reports on the human trials of 
arsphenamine. Ehrlich had been extremely anxious about these trials, and was overjoyed at the favourable reports.

Dr. Lees asked if the lecturer had any historical clues to the partiality of neurologists for treatment of syphilis with mercury.

Mr. Johnston Abraham said, in reply to Col. Harrison, that Dr. Pangloss in Voltaire's Candide had undoubtedly a mixture of mercurial poisoning and syphilis, and had suffered considerably from treatment. A patient should not lose his teeth as a result of treatment by mercury. That was due to over-treatment. In the eighteenth century people lost teeth early not from syphilis but from lack of conservative dentistry.

He thought there was a good deal of evidence that patients seemed better from treatment with mercury in the early stages of gonorrhœa. The old physicians were not so stupid as one might think ; they had to work on clinical signs; and patients with gonorrhœa did seem to improve. But the main benefit they derived was a negative one : they did not have injections into the urethra of corrosive substances such as silver nitrate and zinc chloride-substances which produced strictures. If they had mercury alone these were avoided.

He was pleased to hear that other clinicians thought patients sometimes benefited from Zittmann's decoction. Zittmann, who published his formula in 1750, compounded it of all the things then used in the treatment of syphilis. It was a blunderbuss prescription, but it got results : some of his (Mr. Johnston Abraham's) former patients treated with it certainly did recover from old tertiary syphilitic-lesions which would not clear up in any other way. He was glad to hear it was still used at the London Hospital. It was also still in the Pharmacopœia of the Lock Hospital, and there was a complete description of how to make it in the British Pharmaceutical Codex of 1934 .

It was quite likely that atoxyl produced eye symptoms because of some alteration in its constitution. Ehrlich bimself found the same. After he had stopped using atoxyl he tried "soamin," which was the same thing under another name. In fact he used it for eighteen months under the impression that it was not atoxyl, and got no bad results at all.

Mr. Johnston Abraham said it was quite a common thing all through the seventeenth century to use mercurialized asses' milk in the treatment of syphilis; he did not know where the idea had begun, but he thought it was quite sound. It was thought that if small children were given milk so treated they would not be so likely to be mercurialized.

Some physicians gave mothers large quantities of mercury, put the babies to the breast, and expected them to get the treatment through the mother's milk. That was done deliberately until quite recently. Whether it was a wise thing to let a syphilitic mother feed a baby who showed no signs of the disease was doubtful, because the baby might acquire it from the mother; but it was a recognized treatment.
He refused to be drawn in to discussing the question of syphilitic bones. Many Americans took it as an insult to America to suggest that the disease originated in Hispaniola. It had always been "passed" on to other people: Spanish to Neapolitan, Neapolitan to French, French to the rest of the world. His own feeling was that it was American in origin.

MAJOR SCOTT asked if there was any check on cases which were treated with mercury from the point of view of the appeasement of clinical signs. It would be rather difficult because mercury discoloured the skin.

Mr. Johnston Abraham said that in the old days one could not tell whether the patient was cured or not. After the Wassermann reaction was introduced a very large number of people who had had syphilis, and had been treated, were tested and many were found to have been cured. He remembered one case, a man of twenty, who was treated by the elder Shillitoe. He then had a primary chancre. When he was forty-two he came back looking for the old doctor. But the son was there instead, and he told him that he undoubtedly had syphilis again, and that he would require re-treatment. This was done. The man returned again when he was sixty-three with what was clinically a primary chancre, and the younger Shillitoe then asked the speaker (J. J. A.) to see him. The man had spirochætes and a negat ve Wassermann reaction, but six weeks later the Wassermann reaction was positive. He was then treated with arsphenamine. This was an example of a man being cured twice by mercury. In the old days the only test was the clinical test. If a man was clinically cured one did not bother about him further.

Dr. Lees had spoken of Ehrlich. Ehrlich was extremely careful about all his work. At the present moment he (the speaker) had a manuscript written by Ehrlich's secretary, and in it she gave a very clear and interesting description of all the things Ehrlich did before he allowed arsphenamine to go out into the world. The most interesting point of all was that Ehrlich discovered it in 1906, and it was tried out experimentally by two of his assistants who said that it was no good. It was therefore put aside until Hata, his Japanese assistant, came, and Ehrlich asked him to repeat the earlier experiments with arsphenamine, with arsenophenylglycin, and with atoxyl. Hata kept coming to him and saying: "Arsphenamine is the best drug. All the other drugs are inadequate compared with arsphenamine." When he found this was correct, Ehrlich was furious with his former assistants for letting him down. If they had done their job properly, arsphenamine would have been available in 1907 or 1908 and the other preparations would not have been in use at all.

The last question was: "Why did neurologists have such a touching faith in mercury inunctions?" $\mathrm{He}$ thought it was because they were behind the times. 